\title{
Greek science on the brink
}

\section{Financial woes spur controversial reforms of the country's research system.}

\section{BY ALISON ABBOTT IN ATHENS}

"W e are trying to survive and go along as if nothing is happening," says Dimitra Thomaidou, a microscopist at the Hellenic Pasteur Institute in Athens.

Despite Greece's financial crisis, optimism was the prevailing mood at last month's meeting of the Hellenic Society for Biochemistry and Molecular Biology in Athens, where Thomaidou coordinated a session. Meeting attendance was at a record high, and chat was full of references to fancy equipment purchases and Greek success in winning participation in European research-infrastructure programmes.

But as the financial crisis deepens and university and research spending, already among the lowest in Europe, shrink further, staying optimistic is a constant battle. Academic salaries have been cut by $20 \%$ and university budgets have halved since the crisis began about two years ago. Still, money from the European Commission and international grants is keeping the best Greek scientists committed to their work. "It may sound irrational, but we just don't think we can live without our research," says Thomaidou.

Closer conversation, however, reveals anxiety - not about money, but about reforms spurred by the crisis. Just a handful of Greece's universities and research institutions are internationally competitive. A massive restructuring of the system would modernize their governance, giving them more autonomy while introducing greater competition and transparency. Some institutes and universities would be merged to reduce the fragmentation that has arisen in the

"It may sound irrational, but wejust don't think we can live without our research." past 30 years. Expected to take effect this year, the plan also aims to break down barriers that make it difficult for scientists to move between institutions.

Scientists' main concern, says Thomaidou, is that mid-career researchers like herself will survive the upheavals only to find that there is no new generation of researchers to succeed them, because poorly paid and financed research careers are unattractive. "We keep our thoughts firmly on science and hope that things will get better - and that if everything is to be restructured, it will be

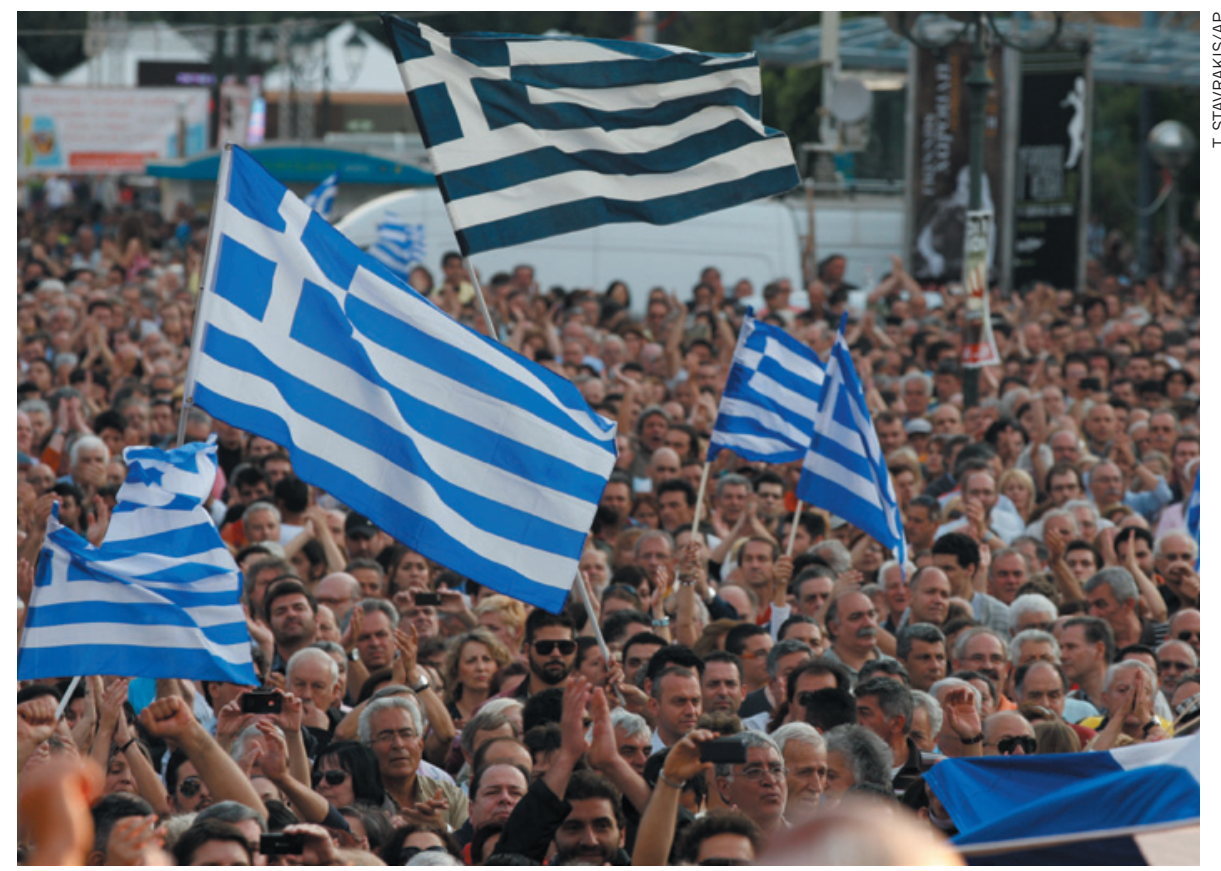

Despite rallies against austerity in Greece, there is growing acceptance of the need for university reform.

done appropriately," she says.

Many scientists in Greece accept that their research system needs restructuring. Previous governments failed to win parliamentary support for reform, but the financial crisis has helped to break down resistance, says Achilleas Gravanis, a pharmacologist at the University of Crete in Heraklion and chairman of the biosciences section of the National Council for Research and Technology, which advises the government. A new law for higher education was approved with a huge majority by the Greek parliament on 24 August 2011, and next month a draft law for research should be presented to parliament, where it is expected to have an easy ride.

The academic leadership of the 18 publicly funded research centres in Greece is generally positive about the reforms. "Only good things are likely to happen," says Dimitris Thanos, a molecular biologist and research director at the Bioacademy in Athens. But scientists in smaller research institutes dread being told to merge with universities, saying that their agility could be crushed by university bureaucracy.

The rectors of Greece's 24 public universities, for their part, seem appalled by the law, which radically changes university governance, depoliticizing it and bringing it into line with European norms. Students will lose their right to vote for department chairs, deans and rectors. Each university will be responsible for its own budget and must appoint a powerful governing council with 15 members: six from outside the university, and just one student representative. The council will draw up a shortlist for the position of rector, on which faculty members will vote.

\section{REBELLIOUS RECTORS}

Implementation of the law has stalled because rectors are appealing to the Constitutional Court, claiming that the presence of external council members violates their academic independence. Gravanis disagrees with this opposition: "It is shocking that academic leaders would show no respect for a law passed with huge parliamentary majority," he says. The law was designed with input from a constitutionalcourt judge, he adds.

Only the University of Crete is complying with the changes. It is to hold elections for internal members of its council on 22 February. "We'll just have to see how we can make the law work well in practice," says its rector, Euripides Stephanou. But he is nervous. The financial crisis may have encouraged the approval of reform laws, he says, but cash shortages may encourage the incoming governing councils to close faculties that have no revenue-generating potential — such as the University of Crete's prestigious 
- archaeology and history departments.

The proposed law on research would also need solid financial backing, say scientists. It designs a system in which researchers in different types of institution and in industry would be able to collaborate easily, administration would be efficient and there would be regular calls for competitive research grants. The law would create a mandatory line for research spending in the state budget for the first time. But parliament would have to approve the actual budget each year, and scientists fear that parliament might not be generous.

Greece does not have a dedicated research funding agency, but that absence is offset by the $€ 0.9$ billion (US $\$ 1.14$ billion) earmarked for research from the country's 2007-13 European Union (EU) Structural Funds, which are effectively subsidies for poorer regions in the union. After years of providing almost no research funding, the Greek government has in the past year put out a handful of calls for infrastructure and competitive-research grant proposals that would use the EU money. Most calls invite applications from academic networks and industry collaborations, but one, made last May, is aimed at individual researchers. Modelled on grants offered by the European Research Council, the calls are worth up to $€ 1$ million each. But competition is harsh: of 1,200 applications, fewer than 200 will be funded.

The money will be a life-saver for established researchers, but the future of the system as a whole remains uncertain. Over the next five years, $30 \%$ of current faculty members and researchers will retire from Greek universities and research centres, and replacing them may be difficult. Thanks again to EU funding, Greece produces large numbers of PhDs, but most of those who continue on to postdoctoral research do so abroad. In the past, many have returned to seed competitive research groups at home. The proposed law provides schemes to encourage that, but few believe that it will work, given the very low salaries and uncertain funding that researchers can expect.

Vasso Kostourou, a cell biologist at the Alexander Fleming Biomedical Sciences Research Center in Vari, is an exception. She returned to Greece from London in 2008, and recalls colleagues encouraging her because they thought that project funding was about to resume. Instead, she arrived as the crisis hit. At 37 years old, Kostourou thinks that she may be among the last scientists to return to academia in Greece for the foreseeable future. "That's

\section{NATURE.COM} Listen to an interview about the Greek crisis at: go.nature.com/kwsh4c a shame because the quality of science that can be done here is high," she says. "It's only the funding that's bad." -

\section{Disaster toll tallied}

\author{
The soaring cost of natural catastrophes is due more to \\ socio-economic than climatic factors.
}

\section{BY QUIRIN SCHIERMEIER}

$\mathrm{N}$ atural disasters around the world last year caused a record US $\$ 380$ billion in economic losses. That's more than twice the tally for 2010 , and about $\$ 115$ billion more than in the previous record year of 2005, according to a report from Munich Re, a reinsurance group in Germany. But other work emphasizes that it is too soon to blame the economic devastation on climate change.

Almost two-thirds of 2011's exceptionally high costs are attributable to two disasters unrelated to climate and weather: the magnitude-9.0 earthquake and tsunami that hit Japan in March, and February's comparatively small but unusually destructive magnitude-6.3 quake in New Zealand.

And the long-term rise in the costs of global disasters is probably due mainly to socio-economic changes, such as population growth and development in vulnerable regions. That conclusion is backed up by a forthcoming study - supported by Munich Re - by economists Fabian Barthel and Eric Neumayer at the London School of Economics. Their analysis of events worldwide between 1990 and 2008 concludes that "the accumulation of wealth in disaster-prone areas is and will always remain by far the most important driver of future economic disaster damage" (F. Barthel and E. Neumayer Climatic Change; in the press). Any major weather event hitting densely populated areas now causes huge losses because the value of the infrastructure has increased tremendously, they note, adding that if the 1926 Great Miami hurricane happened today, for example, it would cause much more damage than it did at the time.

However, weather-related events are generally on the rise. Thanks to a relatively quiet Atlantic hurricane season, damage caused by extreme weather was actually lower in 2011 than in four of the previous five years. But weather accounted for about $90 \%$ of the year's 820 recorded natural disasters, which caused at least 27,000 deaths. These disasters include flooding in Thailand, a series of tornadoes that hit the United States Midwest and southern states last spring, and storms and extreme rainfall over parts of the Mediterranean in November.

Since 1980, the report notes, the number of severe floods has almost tripled, and storms have nearly doubled, which insurance experts link, in part, to the impact of climate change (see 'Catastrophe count'). "It would not seem

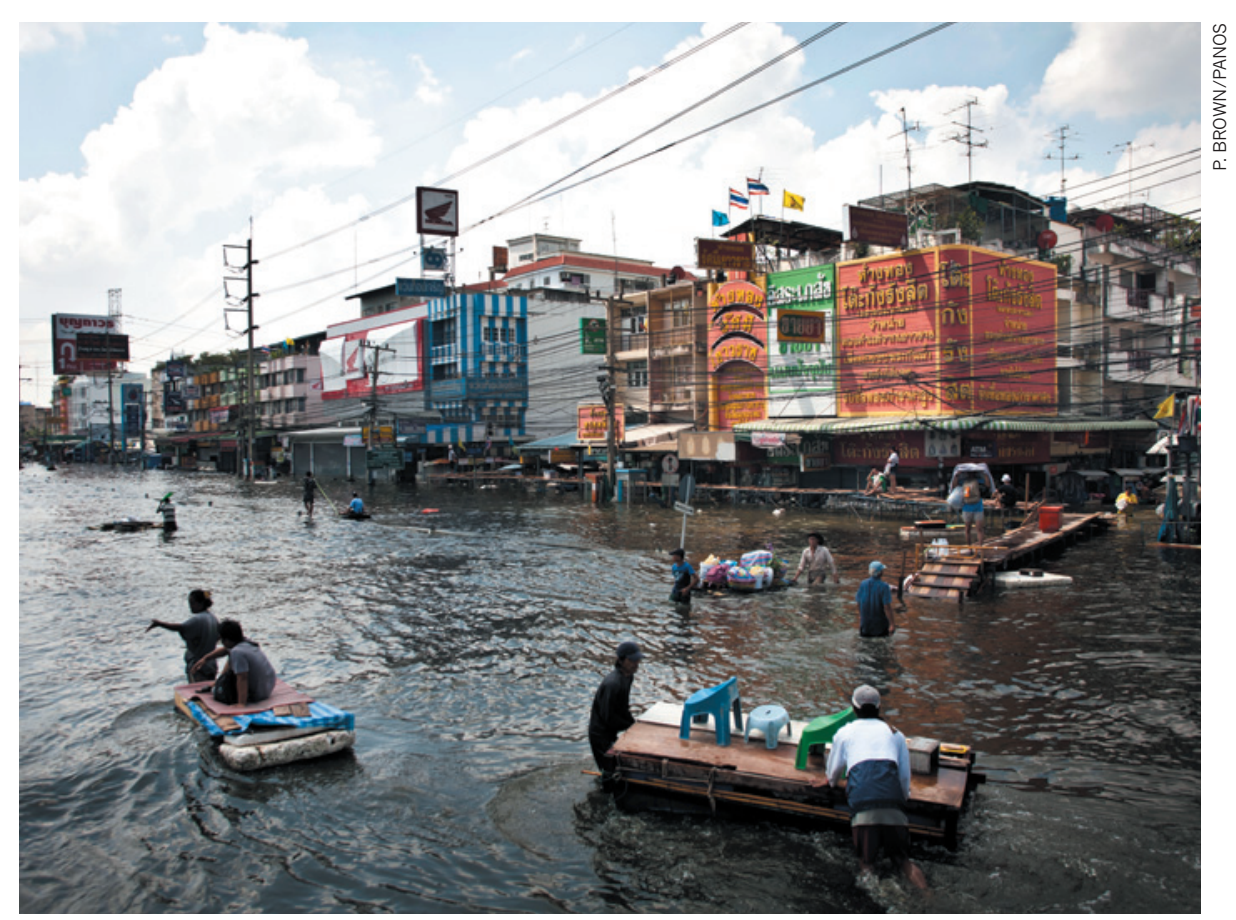

Heavy rains turned roads into rivers last year as Thailand experienced its worst flooding in 50 years. 